\title{
Reading Habit in Digital Era: Indonesian People do not Like Reading, is it True?
}

By

Nuning Kurniasih

Department of Library and Information Science, Faculty of Communication Science, Univeritas Padjadjaran, Jl. Raya Bandung-Sumedang KM.21 Jatinangor Sumedang 45363

Email: nuning.kurniasih@unpad.ac.id ; nuningkurniasih@yahoo.com

Published at Web Culture Forum's Site

https://worldcultureforum-bali.org/reading-habit-in-digital-era-indonesian-people-do-notlike-reading/ (26 September 2016)

\begin{abstract}
Various surveys indicate very low rates of reading interest in Indonesia. Then a question emerges; can printed books reading interest represent the overall reading habit? How is the contribution of reading through online media to the index of Indonesian reading interest? Digital era has changed society's reading behavior. Thus, the parameters of reading interest need to be revised. There are at least five elements need to be considered in assessing reading interest in the digital era, namely (1) The Essence of Reading (2) The Technology Evolution (3) The Society Characteristic in Digital Era (4) Reading as Social Activity (5) Reading Behavior in Digital Era. However, there are some points need to be considered, namely: (1) Adequate infrastructure (2) Human resources capability (3) Reading sources. Considering the change of reading behavior, reading interest is not necessarily about how many books have been read, but also how many of information sources or online reading materials have been clicked, read, shared, discussed, saved or downloaded. It is the key for government or decision makers to provide good quality reading sources online and how is the contribution of reading through online media to the index of reading interest based on online readers needs, interests and behavior.
\end{abstract}

Keywords: Reading Habit, Reading Interest, Digital Era, Digital Native, Reading Sources, Online Media

\section{Introduction}

Various surveys indicate very low rates of reading interest in Indonesia. In 2015, National Library released data shown only $10 \%$ of Indonesian whom on the age above 10 years old interest in reading (Wibowo 2015). Then a question emerges; can the presently reading interest represent the overall reading habit, considering the availability of various types of reading media nowadays? The advancement of information technology and communication has transformed the society's characteristics and culture, including its reading behavior. Therefore, the parameters of reading interest need to be adjusted to the transformation currently exist.

\section{Reading Elements in Digital Era}

There are at least five elements need to be considered in assessing reading interest in the digital era, namely:

\section{The Essence of Reading}

Basically, reading is languages ability through texts understanding aimed to gain information, increase knowledge, entertainment, and self-development. Thus, texts in any forms stimulate readers' mind to achieve certain goals can be regarded as reading activity. Then the next stage is to analyze the reading materials, the source, the media, and the reading goals. Knowing the reading materials help to develop the collection of information sources or reading materials, in order to provide readers with good quality reading materials and reliable sources. Meanwhile, knowing the reading media is needed to generate a strategy to distribute information or reading materials. Good quality reading materials hopefully will encourage people to produce beneficial output.

\section{The Technology Evolution}

Indonesian society was born with oral tradition. The children are familiar with folklore and fairytale since they were born. Before writing introduced, historical stories were delivered 
orally. Then after writing introduced, the historical scripts and inscriptions were finally found. Reading culture was growing but could not overcome the oral tradition. Internet technology was established since 1960ish, but the term "internet" itself only had been known in 1980ish. Back in 1980ish, ICT was very limited and printed books were still the primary reading media.

In 1982, CD was released as an alternative information storage media. Then, lots of manual books took form of $\mathrm{CD}$ and there were additional information in $\mathrm{CD}$ along with printed books.

In 1995, website were developed with the born of GeoCities. In other words, the types of information media as well as reading media were increased with the emergence of digital media. In 2004, Google introduced "Google Print" that has been known as "Google Book" now, a services provide full text books and magazines in digital form (scanned files) from Google, which in cooperation with amounts of publishers around the world. Books access has become a lot easier with the availability of digital services and e-book. Then, digital library was developing. The society tends to get information from various sources faster than before, it even becomes faster when social media hit a rapid growth in 2000ish.

\section{The Society Characteristic in Digital Era}

The society characteristic has transformed along with the evolution of ICT. The society nowadays, specially the digital native generation, tends to be online all the time. They want to get multisource information in multimedia form immediately; they are multitasking; they interact real time and create contents limitlessly. It eventually affects their reading needs and behavior.

\section{Reading as Social Activity}

As a matter of fact, social media has started in 1978 in the form of bulletin board, then followed by classmates, six degree, and blogs. Then, it grew rapidly in 2000 with Friendster, LinkedIn, MySpace, Facebook, Twitter, Wiser, Google+, etc. The growth of social media has affected message distribution process and communication pattern.

Social media growth enables real time interaction. Reading then becomes a social activity (Fuller and Sedo 2014). People use social media to share reading materials, discussing it, and then even produce new contents out of it. The dissemination of reading materials through social media in Indonesia is very potential, considering the amount of social media users in Indonesia has reached 66 million out of 88,1 million internet users in Indonesia (Kemp 2016).

\section{Reading Behavior in Digital Era}

Message on online media, especially social media, has its own characteristics, that is: everyone can generate information; message delivered briefly; information distribution is incredibly fast and simultaneously; also there is interaction among the users, both real time and non real time. Then, society's reading behavior changed. As if the world is in our hand only by having a gadget. Actually, people do reading all the time, whether reading web contents, news contents, news feed on social media, e-book, email, etc. Accessing reading materials is only a thumb away. In one hand, people tend to do things quickly, so they read the contents briefly without a proper attention then share it shortly without accuracy check. It is as if everyone wants to be the first source of the information. On the other hand, there is a potential to revive the reading habit. We can make use of people tendency to actualize themselves in social media to popularize reading habit. 
Considering the change of reading behavior, reading interest is not necessarily about how many books have been read, but also how many of information sources or online reading materials have been clicked, read, shared, discussed, saved or downloaded.

\section{Data on the Amount of Online News Readers in Indonesia}

The survey result of Global Research Institution GFK and Indonesian Digital Association (IDA) in 2015 indicated $96 \%$ of news consumption is via online media (Ali 2016), which means only $4 \%$ of it via printed media (newspaper). The statistics of online news in Indonesia is as follows:

Table 1

Statistics of Daily Visitor and Page views on Online News Site in Indonesia

\begin{tabular}{|l|c|r|r|}
\hline \multicolumn{1}{|c|}{ Online News Site } & Last Scanned & Daily Visitors & Daily Page views \\
\hline detik.com & 8 September 2016 & 1.125 .900 & 6.676 .788 \\
\hline kompas.com & 3 September 2016 & 646.654 & 3.039 .274 \\
\hline liputan6.com & 3 September 2016 & 598.784 & 1.880 .183 \\
\hline tribunnews,com & 3 September 2016 & 461.732 & 2.622 .642 \\
\hline merdeka.com & 3 September 2016 & 335.587 & 1.281 .943 \\
\hline viva.co.id & 3 September 2016 & 254.429 & 859.970 \\
\hline okezone.com & 3 September 2016 & 247.239 & 998.847 \\
\hline tempo.co & 8 September 2106 & 199.883 & 635.630 \\
\hline republika.co.id & 2 September 2016 & 178.784 & 561.384 \\
\hline suara.com & 7 September 2016 & 129.426 & 336.510 \\
\hline
\end{tabular}

Data Source: (Website Infomer 2016)

The Table 1 above shows the daily page views of detik.com reached 6.676.788. By the average more than $90 \%$ of Indonesian readers on each site, then how is the contribution of reading through online media to the index of Indonesian reading interest? The contribution of reading through internet in Indonesia is very potential, considering the amount of internet users in Indonesia.

\section{Information Access and Digital Gap}

Digital era provides facility and velocity in accessing information. However, there are some points need to be considered, namely:

1. Adequate infrastructure. The accessibility of reading materials plays big role in affecting reading interest. Although gadget usage has reached remote areas in Indonesia, but the digital gap is big. At least, internet connection and PC need to be provided for the society.

2. Human resources capability. Digital literacy is needed as guidance for the society to connect with the digital world.

3. Reading sources. In 2015, National Library stated that the increasing number of libraries in Indonesia is followed by the decreasing number of its visitors. The cause was the limited numbers of collection provided by libraries (Nurhandoko 2015). Entering digital world means we have to be ready with digital reading materials.

\section{Conclusion}

Digital era has changed society's reading behavior. Thus, the parameters of reading interest need to be revised. Reading interest can no longer be assessed by how many books have been read, but also how many reading materials online have been clicked, read, shared, discussed, saved, or downloaded. It is the key for government to provide good quality reading sources online based on online readers needs, interests and behavior. 


\section{References}

Ali, Syukron. 2016. Konten Sosial dan Hiburan Jadi Konsumsi Berita Favorit. March 19. Accessed September 6, 2016. http://swa.co.id/swa/trends/business-research/konten-sosial-danhiburan-jadi-konsumsi-berita-favorit.

Fuller, Danielle, and DeNel Rehberg Sedo. 2014. "And Then We Went to the Brewery": Reading as a Social Activity in a Digital Era." World Literature Today. Norman, OK: World Literature Today, May-August.

Kemp, Simon. 2016. Digital in 2016: We Are Social's Compendium of Global Digital, Social and Mobile Data Trends and Statistics. Special Report, Singapore: wearesocialsg.

Nurhandoko. 2015. Pengunjung Perpustakaan Menurun Akibat Koleksi Buku Kurang. May 28.

Accessed August 20, 2016. http://www.pikiran-rakyat.com/jawa-

barat/2015/05/08/326532/pengunjung-perpustakaan-menurun-akibat-koleksi-buku-kurang.

UNESCO. 2014. Reading in the Mobile era: A Study of Mobile Reading inDeveloping Countries. Study Report in Education Sector, Paris: Unesco.

Verma, Jyoti, and Sharad Kumar Sonkar. 2013. "Impact of E-Resources and Web Technology on Reading Habits." In Challenges of Academic Library Management in Developing Countries, by S. Thanuskodi, 68-74. USA: IGI Global.

Website Infomer. 2016. Complete Information About Any Website. September 8. Accessed September 8, 2016. http://website.informer.com.

Wibowo, Wahyu. 2015. Kebiasaan Membaca Buku Masyarakat Indonesia Rendah. October 28.

Accessed September 8, 2016.

http://rri.co.id/post/berita/213647/nasional/kebiasaan_membaca_buku_masyarakat_indon esia_rendah.html.

\section{Brief of Author Biography}

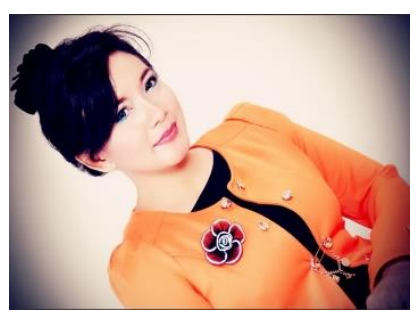

Nuning Kurniasih holds Master degree in Library and Information Science from Univesitas Indonesia. She started her career in 2000 as Lecturer and Researcher at Universitas Padjadjaran (Unpad), Bandung, Indonesia, where she served as Secretary of Public Relations, Head of Computer Laboratory etc and currently is heading the Computer Mediated Communication Laboratory at Faculty of Communication Science. She joined the project on Historical Archive for Human Evolution and Development at Leiden University, Netherlands in 2011. She is representing Indonesia in the Editorial Board of ELIS since 2016, Country Coordinator in International Librarian Network (ILN) in 2014 and Editorial Board of "Journal of "Informatics Studies" since 2014. Her research interest are Information Economics, Social Media, Information Retrieval, Digital and Cultural Literacy, Health Information, Informatics/Altmetrics, Digital Archiving and ICT application for knowledge management. She achieved "The Top Conference Paper Myung-Seok Park Award" from Pacific and Asian Communication Association (PACA) 2014 and Satya Karya Bhakti Kelas II from Universitas Padjadjaran (2016). More about Ning : www.nuningkurniasih.wix.com/ladangilmu 